\title{
PENGARUH KUALITAS PRODUK DAN KUALITAS PELAYANAN TERHADAP MINAT BELI ULANG D'FRESCO DONUT MELALUI KEPUASAN PELANGGAN SEBAGAI VARIABEL PEMEDIASI
}

\author{
Handayani Tri Wijayanti \\ STIE Atma Bhakti \\ e-mail : yanidiawan@yahoo.co.id \\ Siti Almaidah \\ STIE Atma Bhakti \\ e-mail : almaidah.elmuhammad@gmail.com
}

\begin{abstract}
The culinary business in Solo continues to grow along with the development of Solo City to become one of the tourist destinations in Indonesia. One of the culinary businesses that is growing is typical snacks of Solo City and present cakes. Currently, the most popular cakes include donuts. Changes in consumer tastes and market demands require companies to make innovative and creative efforts towards their products and marketing strategies. This study was intended to examine the effect of product quality and service quality on D'Fresco Donut repurchase interest through customer satisfaction as the mediating variable. The sample in this study amounted to 150 respondents. The sampling procedure uses accidental sampling. The analysis techniques used include: (1) descriptive analysis, (2) testing research instruments, (3) classical assumption test, and (4) path analysis. The results showed that there was an effect of product quality and service quality on repurchase interest mediated by customer satisfaction.
\end{abstract}

\begin{abstract}
ABSTRAK
Bisnis kuliner di Kota Solo terus berkembang seiring dengan perkembangan Kota Solo menjadi salah satu tujuan wisata di Indonesia. Salah satu bisnis kuliner yang sedang berkembang adalah jajanan khas Kota Solo dan kue kekinian. Saat ini kue kekinian yang sedang digemari tersebut diantaranya adalah Donat. Perubahan selera konsumen dan permintaan pasar menuntut perusahaan untuk melakukan upaya inovatif dan kreatif terhadap produk dan strategi pemasarannya. Penelitian ini dimaksudkan untuk menguji tentang pengaruh kualitas produk dan kualitas pelayanan terhadap minat beli ulang D'Fresco Donut melalui kepuasan pelanggan sebagai varibel pemediasi. Sampel dalam penelitian ini berjumlah 150 responden. Prosedur pengambilan sampel menggunakan accidental sampling. Teknik analisis yang digunakan diantaranya: (1) analisis deskriptif, (2) pengujian instrumen penelitian, (3) uji asumsi klasik, dan (4) path analysis. Hasil penelitian menunjukkan bahwa terdapat pengaruh kualitas produk dan kualitas pelayanan terhadap minat beli ulang dengan dimediasi kepuasan pelanggan.
\end{abstract}

Kata Kunci : Kualitas produk, Kualitas pelayanan,Kepuasan pelanggan, Minat beli ulang. 


\section{Buletin Ekonomi}

\section{PENDAHULUAN}

Dewasa ini bisnis kuliner di kota Solo mengalami peningkatan baik dari segi kuantitas ataupun kualitas. Kota Solo merupakan salah satu tujuan wisata di tanah air, dan dikenal dengan keragaman kulinernya. Bisnis kuliner telah menjadi salah satu komponen penting perekonomian di kota Solo. Pemerintah Kota (Pemkot) Solo mencatat perputaran uang dari sektor kuliner minimal menembus angka Rp310 miliar setahun. Menurut Kepala Badan Pendapatan Pengelolaan Keuangan dan Aset Daerah (BPPKAD) Solo, penggemar kuliner PKL diprediksi lebih banyak dibanding yang masuk ke restoran. Tempat makan yang lebih banyak dikunjungi oleh wisatawan adalah warung tradisional dan Pedagang Kaki Lima (PKL) (Wibowo: 2017).

Salah satu bisnis kuliner yang sedang marak adalah jajanan khas kota Solo dan kue kekinian, yang tumbuh seiring dengan perubahan selera konsumen dan permintaan pasar. Kue kekinian yang sedang digemari tersebut diantaranya adalah Donat, yang ditawarkan dengan berbagai topping, dan varian rasa, serta dikemas dalam kemasan yang menarik. Donat merupakan olahan makanan yang digemari oleh berbagai kalangan dan cukup mudah didapatkan, karena dijual di toko-toko kue atau PKL dengan harga yang terjangkau. Dalam perkembangannya semakin banyak merek donat yang tersebar di kota Solo, ada yang dari luar negeri hingga merek lokal. Diantara merek lokal ada yang namanya D'Fresco Donut, merupakan UKM yang sedang tumbuh. Memiliki tempat penjualan sejumlah delapan tempat yang tersebar di wilayah Solo dan Sukoharjo. Dalam rangka meningkatkan kinerjanya D'Fresco Donut berupaya memberikan yang terbaik kepada konsumennya sehingga akan datang kembali untuk membeli produknya.

Perkembangan pesat pada bisnis kuliner Donat baik secara kuantitas dan kualitas mengakibatkan persaingan yang tajam. Kondisi tersebut menuntut perusahaan untuk dapat memenuhi kebutuhan, keinginan, dan perubahan selera konsumen. Selain itu perusahaan juga dituntut untuk bersaing secara kompetitif dalam memuaskan konsumen, yang pada akhirnya akan membentuk minat beli ulang terhadap produknya. Konsumen akan melakukan pembelian ulang setelah membeli produk tertentu untuk digunakan atau dikonsumsi, selanjutnya berminat untuk membeli ulang produk yang sama. Menurut Kotler dan Keller (2009) menyatakan bahwa minat beli ulang merupakan suatu keinginan atau tindakan untuk melakukan pembelian ulang pada suatu produk, karena konsumen merasa puas terhadap produk yang sama tersebut. Sedangkan Tjiptono (2014) menjelaskan hal yang sama mengenai minta beli ulang, dinyatakan sebagai pembelian suatu produk yang terjadi berulang kali. Biasanya perusahaan akan mengarahkan tujuan kegiatan pemasarannya pada penciptaan pembelian ulang konsumennya. Pencapaian tujuan tersebut bisa dilakukan dengan berbagai strategi diantaranya adalah peningkatan dalam hal kualitas produknya, kualitas pelayanannya, dan memperhatikan kepuasan konsumennya.

Produk merupakan segala sesuatu yang ditawarkan kepada konsumen untuk dikonsumsi atau digunakan. Konsumen dalam memilih produk akan memperhatikan kelebihan dari nilai guna produk tersebut. Sehingga perusahaan dituntut untuk menawarkan produk yang berkualitas melebihi yang ditawarkan oleh pesaing. Kualitas produk menunjukkan kemampuan suatu produk untuk melaksanakan fungsinya yang meliputi antara lain daya tahan, kehandalan, kemudahan pengemasannya dan karakteristik nilai lainnya (Kotler dan Amstrong: 2008). Kualitas produk yang baik merupakan unsur penting untuk memenangkan persaingan. Kotler dan Amstrong (2008) juga menyatakan bahwa hanya perusahaan yang kualitas produknya melebihi pesaing yang akan tumbuh dan bertahan untuk jangka waktu panjang. Penelitian yang dilakukan oleh Sartika (2017) menunjukkan bahwa terdapat pengaruh positif dan signifikan kualitas produk terhadap minat beli ulang produk minuman You See 1000. Berikutnya studi yang dilakukan oleh Muliawan (2018), 


\section{Buletin Ekonomi}

menemukan bahwa food quality berpengaruh positif terhadap minat beli ulang konsumen pada produk Sari Roti di Surabaya.

Persaingan yang ketat di bisnis kuliner menuntut perusahaan meningkatkan kualitas pelayanan secara lebih baik untuk memberikan kepuasan pada konsumen. Kualitas pelayanan yang baik akan memberikan dampak yang baik pula pada keberhasilan strategi pemasaran dalam jangka panjang. Cronin dan Taylor (1992) mengemukakan bahwa service quality berpengaruh positif terhadap minat beli ulang konsumen dan bersedia merekomendasikan kepada orang lain. Sedangkan penelitian yang dilakukan oleh Faradiba (2013), menemukan bahwa kualitas pelayanan berpengaruh positif terhadap minat beli ulang konsumen pada warung makan Bebek Gendut Semarang.

Satu hal yang harus menjadi perhatian perusahaan bahwa proses konsumsi yang dilakukan oleh konsumen tidak hanya berhenti setelah proses konsumsi selesai, tapi akan ada proses lanjutan yaitu evaluasi terhadap produk. Hasil dari proses evaluasi tersebut adalah konsumen merasa puas atau tidak puas. Studi yang dilakukan oleh Lumintang dan Jopie J. (2015) menemukan bahwa kualitas produk memiliki pengaruh yang signifikan terhadap kepuasan konsumen Holland Bakery Boulevard Manado. Sedangkan penelitian oleh Amanah (2010), menjelaskan bahwa kualitas produk berpengaruh terhadap kepuasan konsumen Majestyk Bakery \& Cake Shop cabang H. M. Yamin Medan.

Sementara itu Parasuraman, et al. (1988) mengungkapkan bahwa semakin tinggi tingkat kualitas pelayanan yang dipersepsikan, semakin meningkat pula kepuasan konsumen. Kualitas pelayanan merupakan hal yang mendahului kepuasan konsumen (Oliver: 1993). Sedangkan berdasarkan studi yang dilakukan oleh Bahar dan Sjahruddin (2015) ditemukan adanya pengaruh yang positif antara kualitas pelayanan terhadap kepuasan konsumen di McDonald's Alauddin Makassar. Hasil yang sama juga ditemukan pada penelitian yang dilakukan oleh Maria dan Yusak (2013), yaitu terdapat pengaruh positif antara kualitas pelayanan terhadap kepuasan konsumen King Cake.

Beberapa studi sebelumnya menunjukkan bahwa kualitas produk dan kualitas pelayanan dapat mengakibatkan konsumen mendapatkan tingkat kepuasan. Jika konsumen merasa puas terhadap produk atau jasa yang dibelinya maka akan mendorongnya untuk melakukan pembelian ulang pada produk atau jasa yang sama. Hubungan yang signifikan antara kepuasan konsumen dengan minat beli ulang bisa ditemui pada studi yang dilakukan oleh Molinari, et al. (2008).

Pemilihan D'Fresco Donut didasarkan pada pertimbangan bahwa D'Fresco Donut adalah sebuah UKM dengan bidang usaha kuliner yang sedang tumbuh, tingkat penjualan yang menunjukkan tingkat konsistensi dalam peningkatannya dan senantiasa melakukan inovasi bagi produknya. Selain itu karena besarnya peluang pasar pada bisnis kuliner ini, dan letak penjualan yang strategis sehingga memudahkan konsumen untuk mendapatkan produknya.

Berdasarkan latar belakang yang diuraikan diatas maka penelitian bertujuan untuk menguji pengaruh kualitas produk dan kualitas pelayanan terhadap minat beli ulang dengan kepuasan sebagai variabel pemediasi pada D'Fresco Donut. Hasil penelitian ini diharapkan dapat bermanfaat bagi akademisi maupun praktisi.

Perumusan hipotesis disusun berdasarkan kajian pustaka dan penelitian terdahulu, adapun dalam penelitian ini terdapat beberapa hipotesis. Penelitian yang dilakukan oleh Maria dan Yusak (2013) membuktikan bahwa kualitas produk berpengaruh terhadap kepuasan konsumen King Cake di Surabaya. Demikian pula penelitian yang dilakukan oleh Windarti dan Ibrahim (2017) menemukan bahwa kualitas produk berpengaruh positif dan signifikan terhadap kepuasan konsumen Donat Madu Cihanjuang. Berdasarkan penelitian tersebut, maka hipotesis 1 dapat dirumuskan sebagai berikut: 


\section{Buletin Ekonomi}

H1 : Kualitas produk berpengaruh signifikan terhadap kepuasan pelanggan

Fornell (1992) membuktikan bahwa terdapat hubungan antara kualitas layanan terhadap kepuasan. Berikutnya penelitian yang dilakukan oleh Sulistyawati dan Seminari (2015) menyatakan kualitas pelayanan berpengaruh terhadap kepuasan pelanggan Restoran Indus Ubud Gianyar. Sedangkan penelitian yang dilakukan oleh Gandhy (2018) membuktikan bahwa kualitas pelayanan berpengaruh positif terhadap kepuasan konsumen Dunkin Donuts Gading Serpong. Berdasarkan penelitian tersebut, maka hipotesis 2 dapat dirumuskan sebagai berikut:

H2 : Kualitas pelayanan berpengaruh signifikan terhadap kepuasan pelanggan

Penelitian sebelumnya menyatakan bahwa kualitas produk Starbucks Semarang berpengaruh signifikan terhadap minat beli ulang konsumen (Vinda W. dan Pujotomo, 2015). Demikian pula dengan penelitian yang dilakukan oleh Nurhayati (2016) membuktikan bahwa kualitas produk berpengaruh terhadap minat beli ulang produk Tsabita Bakery di Surakarta. Berdasarkan penelitian tersebut, maka hipotesis 3 dapat dirumuskan sebagai berikut:

H3 : Kualitas produk berpengaruh signifikan terhadap minat beli ulang

Penelitian Pantjawati (2015) membuktikan bahwa kualitas pelayanan berpengaruh terhadap minat pembelian ulang di Kartini Restoran Surabaya Plaza Hotel. Sedangkan penelitian lain adalah penelitian yang dilakukan oleh Murwanti dan Pratiwi (2017), membuktikan bahwa kualitas pelayanan berpengaruh signifikan terhadap minat beli ulang. Berdasarkan penelitian tersebut, maka hipotesis 4 dapat dirumuskan sebagai berikut:

H4 : Kualitas pelayanan berpengaruh signifikan terhadap minat beli ulang

Kepuasan pelanggan merupakan komponen penting dalam mencapai keberhasilan perusahaan, karena kepuasan yang dirasakan oleh pelanggan akan mendorongnya untuk melakukan pembelian kembali pada produk yang sama, dan memberikan referensi untuk orang-orang di sekitarnya. Kepuasan ditunjukkan pelanggan setelah terjadi proses pembelian (Kotler, 2012). Demikian pula penelitian yang dilakukan oleh Imran (2018) membuktikan bahwa terdapat pengaruh yang signifikan kepuasan pelanggan terhadap minat beli ulang. Bahar dan Sjahruddin (2015), pada penelitiannya ditemukan adanya pengaruh yang positif antara kualitas produk dan kualitas pelayanan terhadap minat beli ulang konsumen dengan dimediasi kepuasan. Berdasarkan penelitian tersebut, maka hipotesis 5 dan hipotesis 6 dapat dirumuskan sebagai berikut:

H5 : Kepuasan pelanggan berpengaruh signifikan terhadap minat beli ulang

H6 : Kepuasan memediasi pengaruh antara kualitas produk dan kualitas pelayanan pada minat beli ulang

Kerangka pemikiran dalam penelitian ini ditunjukkan pada gambar 1. Berdasarkan gambar tersebut, kualitas produk dan kualitas pelayanan secara langsung dapat berpengaruh terhadap minat beli ulang. Sedangkan variabel kepuasan dalam penelitian ini diperkirakan berperan pemediasi hubungan antara kualitas produk dan kualitas pelayanan pada minat beli ulang. 


\section{Buletin Ekonomi}

$\varepsilon_{1}$

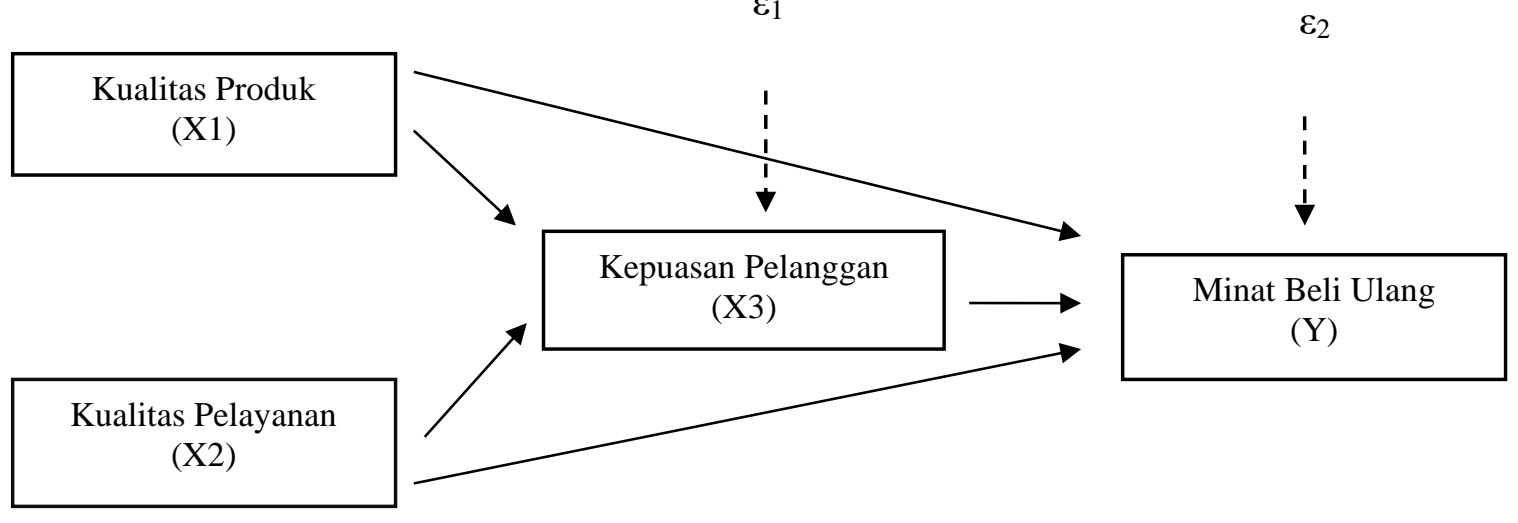

Gambar 1. Kerangka Pemikiran Penelitian Sumber: Dikembangkan untuk penelitian (2020)

\section{METODE}

Desain penelitian yang digunakan dalam penelitian ini adalah penelitian survei, yang mengambil sampel dari suatu populasi dengan meminta tanggapan dari responden melalui kuesioner yang harus diisi. Populasi penelitian mencakup seluruh konsumen D'Fresco Donut dari delapan tempat penjualan, yaitu: (1) dekat kampus Universtitas Muhammadiyah Surakarta, (2) Pasar Gumpang, (3) depan Kantor Desa Gentan Sukoharjo, (4) Purbayan Sukoharjo, (5) Cemani, (6) Mojosongo, (7) Celolo Kadipiro, dan (8) dekat kampus UNS. Sedangkan jumlah sampel yang dilibatkan dalam penelitian ini adalah 150 responden. Kuesioner yang berhasil dikumpulkan sebanyak 150 kuesioner, tetapi kuesioner yang layak untuk diolah datanya adalah 125 kuesioner. Prosedur pengambilan sampel menggunakan accidental sampling, yaitu teknik pengambilan sampel dengan memilih responden yang kebetulan bertemu dengan peneliti saja dan yang merupakan pelanggan D'Fresco Donut.

Variabel independen dalam penelitian ini adalah kualitas produk dan kualitas pelayanan. Adapun yang dimaksud dengan produk menurut Kotler \& Armstrong, (2008) adalah segala sesuatu yang ditawarkan ke pasar untuk mendapatkan perhatian, dibeli, digunakan, atau dikonsumsi sehingga dapat memuaskan keinginan atau kebutuhan konsumen. Produk yang ditawarkan harus memiliki kualitas seperti yang diharapkan oleh konsumen. Sedangkan kualitas sendiri merupakan keseluruhan ciri dan sifat suatu produk atau pelayanan yang memiliki pengaruh terhadap kemampuannya untuk memuaskan kebutuhan konsumen (Kotler, 2012). Pengukuran kualitas produk menggunakan indikator: (1) rasa, (2) kuantitas, (3) ragam atau variasi produk, (4) higienitas, dan (5) inovasi (Essinger dan Wylie, 2003).

Wyckof menyatakan kualitas pelayanan adalah tingkat keunggulan yang ditetapkan perusahaan untuk memenuhi kebutuhan konsumen (Tjiptono, 2014). Sedangkan studi yang dilakukan Wang dan Shieh (2006) menemukan bahwa tingkat kualitas pelayanan yang baik dapat meningkatkan kepercayaan konsumen. Pengukuran kualitas pelayanan menggunakan indikator yang mengadopsi studi yang dilakukan oleh Parasuraman, yaitu (1) realiabilitas (realibility), (2) daya tanggap (responsivebess), (3) jaminan (assurance), (4) empati (empathy), dan (5) bukti fisik (tangibles) (Tjiptono, 2014).

Variabel dependen dalam penelitian ini adalah minat beli ulang. Menurut Mowen dan Minor (2001) menjelaskan minat beli ulang adalah konsumen akan melakukan pembelian pada produk yang sama secara berulang-ulang. Cronin dan Taylor (1992) mengemukakan bahwa konsumen yang merasa puas akan melakukan pembelian ulang pada waktu yang akan datang dan memberitahukan kepada orang lain mengenai produk atau jasa yang dirasakannya. Molinari, et al. (2008), minat beli ulang merupakan penilaian individu tentang pembelian 


\section{Buletin Ekonomi}

ulang atas sebuah produk atau layanan dari perusahaan yang sama, dengan mempertimbangkan pada situasi dan keadaan yang memungkinkan. Pengukuran variabel minat beli ulang dengan menggunakan indikator (1) melakukan pembelian kembali, (2) menjalin relationship dengan produk perusahaan dalam jangka waktu yang lama, dan (3) tetap membeli produk meskipun harga naik.

Variabel pemediasi dalam penelitian ini adalah kepuasan pelanggan. Menurut Tjiptono (2014) menyatakan bahwa kepuasan pelanggan adalah respon terhadap evaluasi ketidaksesuaian atau diskonfirmasi yang dirasakan antara harapan sebelumnya (atau norma kinerja lainnya) dan kinerja aktual produk yang dirasakan setelah pemakaiannya. Kepuasan dapat juga diartikan sebagai tingkat perasaan seseorang setelah membandingkan kinerja yang dirasakannya dengan harapannya (Kotler, 2012). Sedangkan Espejel, et al. (2007) berpendapat bahwa kepuasan bergantung pada perbedaan antara hal yang dirasakan dan dialami antara kualitas produk dan layanan yang terkait. Pengukuran kepuasan pelanggan menggunakan indikator (1) merasa puas (feel satisfied), (2) senang menggunakan produk (happy), (3) harapan yang terpenuhi (expectations have been fulfilled), (4) secara umum puas menggunakan produk (general terms satisfied), (5) puas dengan pengalaman menggunakan produk (satisfied with the experience), dan (6) produk dapat memuaskan kebutuhan (satisfies my needs).

Teknik analisis yang digunakan dalam penelitian ini adalah: (1) analisis deskriptif, (2) pengujian instrumen penelitian yang dilakukan dengan uji validitas yaitu untuk melihat tingkat validitas suatu pernyataan dalam kuesioner (Sekaran, 2003), dan uji reliabilitas dilakukan dengan teknik analisis Cronbach Alpha dengan kriteria bahwa suatu variabel dinyatakan reliabel jika nilai Cronbach Alpha lebih besar dari 0,70 (Nunnaly dalam Ghozali, 2012), (3) uji asumsi klasik yang terdiri dari uji normalitas, uji multikolinieritas, uji heteroskedastisitas, dan uji autokorelasi, (4) path analysis untuk menguji pengaruh kualitas produk dan kualitas pelayanan pada minat beli ulang dengan melibatkan variabel mediasi kepuasan pelanggan (Riduwan dan Kuncoro, 2012).

\section{ANALISIS DAN PEMBAHASAN}

Pada penelitian ini telah disebarkan kuesioner sebanyak 150 kuesioner. Jumlah kuesioner yang dikumpulkan kembali sejumlah 150 kuesioner (respon rate 100\%). Namun demikian dari 150 kuesioner yang diisi lengkap dan bisa diolah sebagai data sejumlah 125 kuesioner. Gambaran umum responden bersumber pada pertanyaan mengenai identitas responden yang meliputi usia, jenis kelamin, tingkat pendidikan, jenis pekerjaan, dan frekuensi pembelian produk. Komposisi dari aspek umur menunjukkan sebaran yang merata dari usia anak-anak sampai dengan usia dewasa, dan lebih banyak yang melakukan pembelian produk D'Fresco Donut lebih dari tiga kali.

Pengujian instrumen dilakukan dengan uji validitas dan reliabilitas. Kriteria suatu pernyataan dalam kuesioner dinyatakan valid atau sahih adalah jika $r$ hitung $>r$ tabel. Hasil uji validitas menunjukkan bahwa seluruh item pernyataan dalam kursioner yang berjumlah 21 dinyatakan valid karena $r$ hitung $>r$ tabel pada tingkat signifikansi 0,05. Sedangkan pada pengujian reliabilitas menunjukkan hasil bahwa kuesioner yang merupakan indikator dari variabel atau konstruk adalah reliabel karena nilai Cronbach Alpha > 0,70 atau dapat dinyatakan semua kuesioner yang digunakan dalam penelitian ini adalah reliabel.

Uji asumsi klasik yang diselesaikan dalam penelitian ini diantaranya adalah:

1. Uji normalitas, yang ditujukan untuk mengetahui data penelitian memiliki sebaran normal atau tidak. Uji normalitas dilakukan dengan uji Kolmogorov-Smirnov. Suatu data memiliki 


\section{Buletin Ekonomi}

sebaran normal jika nilai Asymp Sig (2-tailed) lebih besar dari 0,05. Hasil dari uji normalitas menunjukkan bahwa nilai Asymp Sig (2-tailed) sebesar 0,966 > 0,05. Sehingga dapat dinyatakan data dalam penelitian ini memiliki distribusi normal atau memiliki sebaran yang normal. Hasil uji normalitas ditunjukkan pada tabel berikut:

Tabel 1.

Hasil Uji Kolmogorov-Smirnov

\begin{tabular}{|c|c|c|}
\hline & & $\begin{array}{l}\text { Unstandardized } \\
\text { Residual }\end{array}$ \\
\hline$\overline{\mathrm{N}}$ & & 125 \\
\hline Normal & Mean & $0 \mathrm{E}-7$ \\
\hline Parameters $^{\mathrm{a}, \mathrm{b}}$ & Std. Deviation & 1,97456239 \\
\hline $\begin{array}{l}\text { Most Extreme } \\
\text { Differences }\end{array}$ & $\begin{array}{l}\text { Absolute } \\
\text { Positive } \\
\text { Negative }\end{array}$ & $\begin{array}{l}0,044 \\
0,040 \\
0-, 044\end{array}$ \\
\hline $\begin{array}{l}\text { Kolmogorov-Smirn } \\
\text { Asymp. Sig. (2-taile }\end{array}$ & d) & $\begin{array}{l}0,497 \\
0,966\end{array}$ \\
\hline
\end{tabular}

a. Test distribution is Normal.

b. Calculated from data.

Sumber: data primer diolah

2. Hasil uji multikolinieritas menunjukkan bahwa tidak terdapat gejala multikolinieritas karena semua variabel mempunyai nilai tolerance lebih besar dari 0,10 atau10\%, dan nilai variance inflation factor (VIF) lebih kecil dari 10. Hasil uji multikolinieritas ditunjukkan pada tabel berikut:

Tabel 2.

Hasil Uji Multikolinieritas

\begin{tabular}{lll}
\hline \multirow{2}{*}{ Variabel } & \multicolumn{2}{c}{ Collinearity Statistics } \\
\cline { 2 - 3 } & Tolerance & VIF \\
\hline Kualitas Produk (X1) & 0,856 & 1,168 \\
Kualitas Pelayanan (X2) & 0,963 & 1,038 \\
Kepuasan Pelanggan (X3) & 0,836 & 1,196 \\
\hline
\end{tabular}

Sumber: data primer diolah

3. Uji heteroskedastisitas dilakukan dengan uji park, hasilnya menunjukkan bahwa tidak terdapat gejala heteroskedastisitas karena korelasi antara variabel independen dengan residual memberikan nilai signifikansi lebih dari 0,05 . Hasil uji heteroskedastisitas seperti yang ditunjukkan pada tabel 3 .

4. Uji autokorelasi ditujukan untuk mengetahui ada atau tidaknya korelasi antara anggota dari serangkaian pengamatan yang terletak secara berderetan secara series didalam waktu. Pengujian autokorelasi dilakukan dengan uji Durbin-Watson. Hasilnya menunjukkan tidak terdapat gejala autokorelasi karena nilai terletak pada area bebas autokorelasi yaitu nilai $\mathrm{dU}<\mathrm{dW}<4-\mathrm{dU}$ atau $1,774<1,875<2,226$, atau dapat dinyatakan bahwa tidak ada gangguan autokorelasi pada model regresi. Hasil uji autokorelasi seperti yang ditunjukkan pada tabel 4 . 


\section{Buletin Ekonomi}

Tabel 3.

Hasil Uji Heteroskedastisitas Dengan Uji Park

\begin{tabular}{|c|c|c|c|c|c|c|}
\hline \multirow[t]{2}{*}{ Moc } & & \multicolumn{2}{|c|}{$\begin{array}{l}\text { Unstandardized } \\
\text { Coefficients }\end{array}$} & \multirow{2}{*}{$\begin{array}{l}\text { Standardize } \\
\text { d } \\
\text { Coefficients } \\
\text { Beta } \\
\end{array}$} & \multirow[t]{2}{*}{$\mathbf{t}$} & \multirow[t]{2}{*}{ Sig. } \\
\hline & & B & Std. Error & & & \\
\hline \multirow{4}{*}{1} & (Constant) & 16,527 & 7,069 & & 2,338 & 0,021 \\
\hline & LnX1 & $-2,566$ & 1,587 & $-0,156$ & $-1,617$ & 0,109 \\
\hline & $\operatorname{LnX} 2$ & $-1,585$ & 1,787 & $-0,080$ & $-0,887$ & 0,377 \\
\hline & LnX3 & $-1,287$ & 1,640 & $-0,077$ & $-0,785$ & 0,434 \\
\hline
\end{tabular}

a. Dependent Variable: Lnei2

Sumber: data primer diolah

Tabel 4.

Hasil Uji Autokorelasi

\begin{tabular}{llllll}
\hline Model & R & R Square & $\begin{array}{l}\text { Adjusted } \\
\text { Square }\end{array}$ & $\begin{array}{c}\text { R Std. Error of } \\
\text { the Estimate }\end{array}$ & $\begin{array}{l}\text { Durbin- } \\
\text { Watson }\end{array}$ \\
\hline 1 & $0,618^{\mathrm{a}}$ & 0,382 & 0,366 & 1,999 & 1,875 \\
\hline
\end{tabular}

a. Predictors: (Constant), Kepuasan Pelanggan (X3), Kualitas Pelayanan (X2), Kualitas Produk (X1)

b. Dependent Variable: Minat Beli Ulang (Y)

Sumber: data primer diolah

Pengujian hipotesis dilakukan dengan analisis jalur (path analysis), yang mencakup pengujian persamaan 1 (Sub Struktur 1) dan persamaan 2 (Sub Struktur 2). Analisis regresi untuk persamaan 1 ditujukan untuk menguji pengaruh kualitas produk dan kualitas pelayanan terhadap kepuasan pelanggan. Hasil analisis regresi dengan menggunakan SPSS versi 22 dapat dilihat pada tabel di bawah ini:

Tabel 5.

Hasil Pengujian Persamaan 1

\begin{tabular}{lllll}
\hline Variabel Independen & Beta & t & Sig. & Keterangan \\
\hline Kualitas Produk & 0,342 & 4,208 & 0,000 & Signifikan \\
Kualitas Pelayanan & 0,257 & 3,154 & 0,002 & Signifikan \\
\hline R & 0,455 & & & \\
R Square & 0,207 & & & \\
Adj. R Square & 0,194 & & & \\
F hitung & 15,949 & & & \\
Sig. F & 0,000 & & & \\
\hline
\end{tabular}

Sumber: data primer diolah

Berdasarkan hasil pengujian persamaan 1 dengan analisis regresi linier berganda maka dapat disusun persamaan 1 (sub struktur 1) sebagai berikut:

Kepuasan Pelanggan = 0,342 Kualitas Produk + 0,257 Kualitas Pelayanan + 0,891e1

Persamaan tersebut menjelaskan bahwa koefisien kualitas produk, dan kualitas pelayanan memiliki nilai yang positif, artinya: (1) kualitas produk berpengaruh signifikan terhadap kepuasan pelanggan, artinya semakin meningkat kualitas produk maka akan meningkat pula kepuasan pelanggan; (2) kualitas pelayanan berpengaruh signifikan terhadap kepuasan pelanggan, artinya semakin meningkat kualitas pelayanan maka akan meningkat pula kepuasan pelanggan. 


\section{Buletin Ekonomi}

Uji $F$ atau uji kelayakan model digunakan untuk mengetahui model regresi dalam penelitian layak atau tidak. Berdasarkan hasil ANOVA menunjukkan bahwa nilai $\mathrm{F}$ hitung $>$ F tabel atau 15,949 $>3,071$, dengan nilai signifikansi $0,000<0,05$. Sehingga model yang digunakan dalam penelitian ini adalah layak atau fit. Jadi dapat pula dinyatakan bahwa kualitas produk dan kualitas pelayanan secara simultan berpengaruh terhadap kepuasan pelanggan.

Berdasarkan hasil analisis linier berganda pada persamaan 1 diketahui nilai Adjusted $R$ Square sebesar 0,194 artinya prosentase kontribusi variabel kualitas produk dan kualitas pelayanan sebesar 19,4\% dalam menjelaskan variabel kepuasan pelanggan. Sedangkan sisanya sebesar $80,6 \%$ dijelaskan oleh variabel di luar model. Sementara itu nilai koefisien residu (e1) sebesar 0,891 artinya nilai variance variabel kepuasan pelanggan yang tidak dijelaskan oleh variabel kualitas produk dan kualitas pelayanan sebesar 0,891.

Adapun persamaan 2 (sub struktur 2) menjelaskan hubungan sub struktur kualitas produk, kualitas pelayanan, kepuasan pelanggan terhadap minat beli ulang. Hasil pengujian persamaan 2 (sub struktur 2) ditunjukkan pada tabel di bawah ini:

\section{Tabel 6.}

\section{Hasil Pengujian Persamaan 2}

\begin{tabular}{lllll}
\hline Variabel Independen & Beta & t & Sig. & Keterangan \\
\hline Kualitas Produk & 0,330 & 4,268 & 0,000 & Signifikan \\
Kualitas Pelayanan & 0,248 & 3,405 & 0,001 & Signifikan \\
Kepuasan Pelanggan & 0,301 & 3,854 & 0,000 & Signifikan \\
\hline R & 0,618 & & & \\
R Square & 0,382 & & & \\
Adj. R Square & 0,366 & & & \\
F hitung & 24,908 & & & \\
Sig. F & 0,000 & & & \\
\hline
\end{tabular}

Sumber: data primer diolah

Berdasarkan hasil pada tabel 6 maka dapat disusun persamaan 2 (sub struktur 2) berikut ini:

Minat Beli Ulang $=0,330$ Kualitas Produk + 0,248 Kualitas Pelayanan + 0,301 Kepuasan Pelanggan+0,786e2

Persamaan di atas menjelaskan bahwa koefisien kualitas produk, kualitas pelayanan, dan kepuasan pelanggan memiliki nilai yang positif, artinya: (1) kualitas produk berpengaruh signifikan terhadap minat beli ulang, artinya semakin meningkat kualitas produk maka akan meningkat pula minat beli ulang pelanggan; (2) kualitas pelayanan berpengaruh signifikan terhadap minat beli ulang, artinya semakin meningkat kualitas pelayanan maka akan meningkat pula minat beli ulang pelanggan; (3) kepuasan pelanggan berpengaruh signifikan terhadap minat beli ulang, artinya semakin meningkat kepuasan pelanggan maka akan meningkat pula minat beli ulang pelanggan.

Uji F (uji kelayakan model) untuk persamaan 2 diketahui hasilnya $\mathrm{F}$ hitung $>\mathrm{F}$ tabel atau 24,908 > 2,680 dengan nilai probabilitas (sig) sebesar 0,000 $<0,05$. Sehingga dapat dinyatakan bahwa pengujian secara individual dapat dilanjutkan. Sedangkan pada uji koefisien determinasi dihasilkan nilai Adjusted $R$ Square sebesar 0,366 artinya variabel kualitas produk, kualitas pelayanan, dan kepuasan pelanggan menjelaskan variabel minat beli ulang sebesar 0,366 atau 36,6\%. Sisanya sebesar 63,4\% dijelaskan oleh variabel lain yang tidak termasuk dalam model. Sementara itu nilai koefisien residu $(e 2)$ sebesar 0,786 artinya nilai variance variabel minat beli ulang yang tidak dijelaskan oleh variabel kualitas produk, kualitas pelayanan, dan kepuasan pelanggan sebesar 0,786.

Pengujian hipotesis dilakukan dengan uji t atau pengujian secara parsial pada taraf signifikansi sebesar 0,05 untuk pengujian persamaan 1 dan 2 diperoleh hasil: 


\section{Buletin Ekonomi}

1. Variabel kualitas produk, nilai $\mathrm{t}$ hitungnya $>\mathrm{t}$ tabel atau 4,208 > 1,657 pada tingkat signifikansi (sig) $0,000<0,05$, artinya kualitas produk berpengaruh signifikan terhadap kepuasan pelanggan. Sehingga dapat dinyatakan bahwa hipotesis 1 terbukti dalam penelitian ini. Hasil pengujian ini sesuai dengan penelitian yang dilakukan oleh Maria dan Yusak (2013), Windarti dan Ibrahim (2017), bahwa kualitas produk berpengaruh positif dan signifikan terhadap kepuasan konsumen.

2. Variabel kualitas pelayanan, nilai $\mathrm{t}$ hitungnya $>\mathrm{t}$ tabel atau 3,154 $>1,657$ pada tingkat signifikansi (sig) 0,002 <0,05, artinya kualitas pelayanan berpengaruh signifikan terhadap kepuasan pelanggan maka dapat disimpulkan bahwa hipotesis 2 terbukti. Hasil pengujian ini sesuai dengan penelitian yang dilakukan oleh Fornell (1992), Sulistyawati dan Seminari (2015), Gandhy (2018) bahwa kualitas pelayanan berpengaruh positif terhadap kepuasan konsumen.

3. Variabel kualitas produk memiliki nilai t hitung $>\mathrm{t}$ tabel atau 4,268 $>1,657$ pada tingkat signifikansi (sig) $0,000<0,05$. Artinya kualitas produk berpengaruh signifikan terhadap minat beli ulang. Sehingga dapat dinyatakan bahwa hipotesis 3 terbukti dalam penelitian ini. Hasil pengujian ini sesuai dengan penelitian yang dilakukan oleh Vinda W. dan Pujotomo (2015), Nurhayati, (2016) bahwa kualitas produk berpengaruh signifikan terhadap minat beli ulang konsumen.

4. Variabel kualitas pelayanan mempunyai pengaruh yang signifikan terhadap minat beli ulang, hal itu ditunjukkan oleh nilai $t$ hitung $>\mathrm{t}$ tabel atau 3,405 > 1,657 pada tingkat signifikansi $0,001<0,05$. Maka dapat disimpulkan bahwa hipotesis 4 terbukti dalam penelitian ini. Hasil pengujian ini sejalan dengan penelitian yang dilakukan Pantjawati (2015), Murwanti dan Pratiwi (2017) bahwa kualitas pelayanan berpengaruh signifikan terhadap minat beli ulang.

5. Variabel kepuasan pelanggan memiliki nilai $t$ hitung $>\mathrm{t}$ tabel atau 3,854 >1,657 pada tingkat signifikansi (sig) $0,000<0,05$. Artinya kepuasan pelanggan berpengaruh signifikan terhadap minat beli ulang. Sehingga dapat dinyatakan bahwa hipotesis 5 terbukti dalam penelitian ini. Hasil pengujian ini sesuai dengan penelitian yang dilakukan oleh Imran (2018), bahwa kepuasan pelanggan berpengaruh secara signifikan minat beli ulang.

6. Pengujian variabel kepuasan pelanggan sebagai pemediasi pengaruh kualitas produk dan kualitas pelayanan terhadap minat beli ulang, digunakan Path Analysis dengan uji regresi linier berganda. Hasil pengujian menunjukkan bahwa variabel kepuasan pelanggan sebagai pemediasi pengaruh kualitas produk dan kualitas pelayanan terhadap minat beli ulang adalah signifikan dengan nilai p-value di bawah 0,05 . Sehingga dapat dinyatakan bahwa hipotesis 6 terbukti dalam penelitian ini. Hasil ini sesuai dengan penelitian yang dilakukan oleh Bahar dan Sjahruddin (2015) bahwa terdapat pengaruh yang positif antara kualitas produk dan kualitas pelayanan terhadap minat beli ulang konsumen dengan dimediasi kepuasan.

Hasil pengujian dengan menggunakan analisis jalur atau Path Analysis diketahui bahwa pengaruh langsung kualitas produk dan kualitas pelayanan terhadap minat beli ulang lebih besar dibanding dengan pengaruh tidak langsung, hal tersebut mengindikasikan bahwa konsumen akan melakukan pembelian ulang jika terdapat peningkatan kualitas produk, kualitas pelayanan, dan mendapatkan kepuasan seperti yang diharapkan. Berikut ini tabel yang menunjukkan mengenai hasil besarnya koefisien jalur, pengaruh langsung, dan pengaruh tidak langsung. 
Tabel 7.

Nilai Koefisien Jalur, Pengaruh Langsung, Pengaruh Tidak Langsung, dan Total Pengaruh

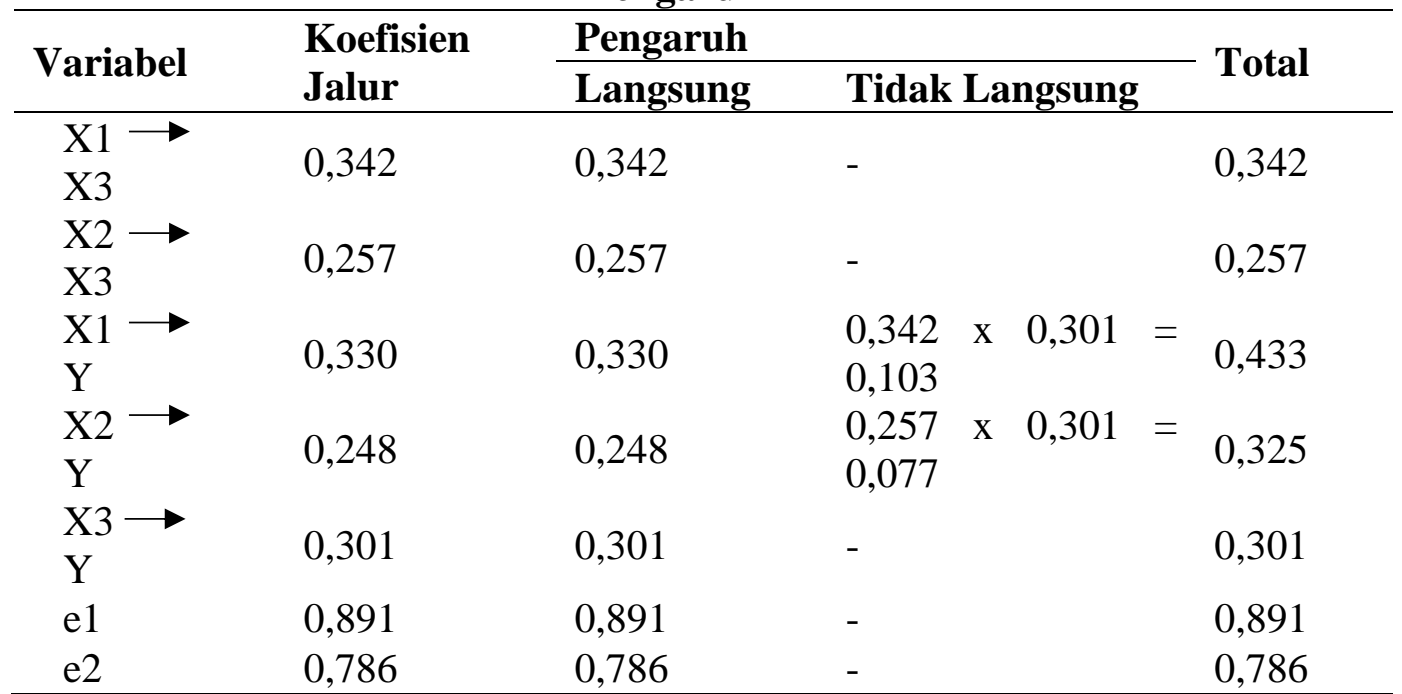

Sumber: data primer diolah

Tingkat signifikansi variabel kepuasan pelanggan sebagai pemediasi pengujiannya dilakukan dengan uji Sobel (Ghozali, 2012). Hasil uji Sobel dalam penelitian ini seperti ditunjukkan pada tabel berikut.

Tabel 8.

\begin{tabular}{lllll}
\multicolumn{5}{c}{ Hasil Uji Sobel } \\
& $\begin{array}{l}\text { Standard } \\
\text { Error }\end{array}$ & $\begin{array}{l}\text { Koefisien } \\
\text { Mediasi }\end{array}$ & $\begin{array}{l}\text { t Statistic } \\
\text { Value }\end{array}$ & $\begin{array}{l}\text { Tingkat } \\
\text { Signifikansi }\end{array}$ \\
\hline $\begin{array}{l}\text { Koefisien indirect effect } \\
1\end{array}$ & 0,035 & 0,103 & 2,913 & 0,05 \\
$\begin{array}{l}\text { Koefisien indirect effect } \\
2\end{array}$ & 0,035 & 0,077 & 2,200 & 0,05 \\
\hline
\end{tabular}

Sumber: data primer diolah

Berdasarkan tabel 8 dijelaskan bahwa standard error pada koefisien indirect effect pengaruh kualitas produk terhadap minat beli ulang dimediasi kepuasan pelanggan sebesar 0,035 dan nilai t statistik pengaruh mediasi sebesar 2,913 > t tabel sebesar 1,657, maka dapat disimpulkan koefisien mediasi 0,103 adalah signifikan yang berarti ada pengaruh mediasi. Sedang untuk standard error pada koefisien indirect effect pengaruh kualitas pelayanan terhadap minat beli ulang dimediasi kepuasan pelanggan sebesar 0,035 dan nilai $\mathrm{t}$ statistik pengaruh mediasi sebesar 2,200 > t tabel sebesar 1,657, sehingga dapat disimpulkan koefisien mediasi 0,077 adalah signifikan yang berarti ada pengaruh mediasi variabel kepuasan pelanggan pada pengaruh kualitas produk dan kualitas pelayanan terhadap minat beli ulang.

\section{KESIMPULAN DAN SARAN}

Beberapa kesimpulan yang bisa ditarik dari hasil penelitian ini adalah terdapat pengaruh yang signifkan kualitas produk terhadap kepuasan pelanggan, terdapat pengaruh yang signifikan kualitas pelayanan terhadap kepuasan pelanggan, terdapat pengaruh kualitas 


\section{Buletin Ekonomi}

produk terhadap minat beli ulang, terdapat pengaruh kualitas pelayanan terhadap minat beli ulang, terdapat pengaruh kepuasan pelanggan terhadap minat beli ulang, dan terdapat pengaruh kualitas produk dan kualitas pelayanan terhadap minat beli ulang dengan dimediasi kepuasan pelanggan.

Adapun saran yang dapat diberikan adalah D'Fresco Donut untuk melakukan peningkatan kualitas produk secara berkesinambungan, karena persaingan pada bisnis makanan donat cukup ketat, Sehingga diperlukan terobosan yang kreatif dan inovotif untuk menghasilkan produk yang diminati oleh konsumen. Selain itu juga senantiasa menjaga kualitas pelayanan dan memenuhi kepuasan pelanggan.

\section{UCAPAN TERIMA KASIH}

Terima kasih kami ucapkan kepada Direktorat Riset dan Pengabdian Masyarakat, Deputi Bidang Penguatan Riset dan Pengembangan Kementerian Riset dan Teknologi/ Badan Riset dan Inovasi Nasional Republik Indonesia yang telah mendukung pendanaan untuk program pengabdian kepada masyarakat skim Program Kemitraan Masyarakat (PKM) untuk tahun anggaran 2020.

\section{DAFTAR PUSTAKA}

Amanah, Dita. (2010). Pengaruh Harga Dan Kualitas Produk Terhadap Kepuasan Konsumen Pada Majestyk Bakery \& Cake Shop Cabang H.M. Yamin Medan. Jurnal Keuangan \& Bisnis, 2(1), Maret 2010, 71-87.

Bahar, Arfiani \& Sjahruddin, Herman. (2015). Pengaruh Kualitas Produk Dan Kualitas Pelayanan Terhadap Kepuasan Konsumen Dan Minat Beli Ulang. Jurnal Organisasi dan Manajemen, 3, September 2015, 14-34.

Cronin, J.J., \& Taylor, S.A. (1992). Measuring service quality: a reexamination and extension. Journal of Marketing, 56, July, 55-68.

Espejel Joel, Carmina Fandos \& Carlos Flavia'n. (2007). The role of intrinsic and extrinsic quality attributes on consumer behaviour for traditional food products. Spain Managing Service Quality, 17(6).

Essinger, James \& Wylie, Helen. (2003). Customer Loyalty: Devising Successful Strategies in Food and Drink. Reuters Business Insight.

Faradiba, Sri Rahayu Tri Astuti. (2013). Analisis Pengaruh Kualitas Produk, Harga, Lokasi Dan Kualitas Pelayanan Terhadap Minat Beli Ulang Konsumen (Studi pada Warung Makan "Bebek Gendut” Semarang). Diponegoro Journal of Management, 2(3), 1-11.

Fornell, Claes. (1992). A National Customer Satisfaction Barometer: The Swedish Experience. Journal of Marketing, 56, 6-21.

Gandhy, Abel. (2018). Analisis Kualitas Pelayanan Dan Kepuasan Konsumen Dunkin Donuts Gading Serpong. Jurnal Manajemen Industri dan Logistik, 2(2), November 2018, 135-146. 


\section{Buletin Ekonomi}

Ghozali, Imam. (2012). Analisis Multivariate dengan Program SPSS, Badan Penerbit Universitas Diponegoro, Semarang.

Imran, Moch Irzad Aditya. (2018). Pengaruh Kepuasan Pelanggan Terhadap Minat Beli Ulang Makanan Di Rumah Makan Ayam Bakar Wong Solo Alauddin Kota Makassar. Jurnal Profitability Fakultas Ekonomi Dan Bisnis, 2(1), 50-64.

Kotler, P. \& Armstrong, G. (2009). Prinsip-Prinsip Pemasaran, Erlangga, Jakarta.

Kotler, Philip \& Kevin Lane Keller. (2009). Manajemen Pemasaran, PT. Indeks, Jakarta.

Kotler, Philip. (2012). Marketing Management, The Millenium Edition, Pretice-Hall International Inc, New Jersey.

Lumintang, Greifie \& Jopie J. Rotinsulu. (2015). Analisis Kualitas Produk Dan Kualitas Layanan Terhadap Kepuasan Konsumen Pada Holland Bakery Boulevard Manado. Jurnal EMBA, 3(1) Maret 2015, 1291-1302.

Maria, Monica \& Yusak, Mohamad. (2013). Jurnal Pengaruh Kualitas Produk Dan Kualitas Layanan Terhadap Kepuasan Konsumen King Cake. Jurnal Manajemen Teori dan Terapan. 6(1), April 2013, 1-9.

Molinari K.L, Russell Abratt, \& Paul Dion. (2008). Satisfaction, quality and value and effects on repurchase and positive word-of-mouth behavioral intentions in a B2B services context. Journal of Services Marketing, 22(5), 363-373.

Mowen, John C \& Michael Minor. 2008. Perilaku Konsumen. Jilid Satu Edisi Kelima. Alih Bahasa: Lina Salim, Erlangga, Jakarta.

Muliawan, Stanley. (2018). Pengaruh Food Quality dan Ketersediaan Produk Terhadap Repurchase Intention Produk Sari Roti di Surabaya. Jurnal Strategi Pemasaran, 5(2), Tersedia pada http://publication.petra.ac.id, Diakses pada tanggal 31 Mei 2020.

Murwanti, Sri \& Pratiwi, Anggrahini Panca. (2017). Pengaruh Kualitas Pelayanan Dan Promosi Terhadap Minat Beli Ulang Jasa Service Motor Dengan Kepuasan Pelanggan Sebagai Variabel Mediasi (Studi Pada Bengkel Motor Ahass Cabang UMS). Prosiding Seminar Nasional Riset Manajemen \& Bisnis 2017, Perkembangan Konsep dan Riset E-Business di Indonesia, ISBN: 978-602-361-067-9, 207-277.

Nurhayati, Khairun. (2016). Analisis Faktor-Faktor Yang Mempengaruhi Minat Pembelian Ulang: Studi Empiris Pada Konsumen Tsabita Bakery di Surakarta. Tersedia pada http://eprints.ums.ac.id, Diakses tanggal pada tanggal 31 Maret 2020.

Oliver, Richard L. (1993). Cognitive, Affective, and Attribute Bases of The Satisfaction. Journal of Consumer Research, 20(3), 451-466.

Pantjawati, J. (2015). Pengaruh Kualitas Layanan Terhadap Minat Pembelian Ulang Melalui Kepuasan Pelanggan Di Kartini Restoran Surabaya Plaza Hotel. Tersedia pada http:// eprints.perbanas.ac.id, Diakses pada tanggal 31 Maret 2020. 


\section{Buletin Ekonomi}

Parasuraman, A. Zeithaml, V.A., Berry L.L. (1988). SERVQUAL: A Multiple-Item Scale for Measuring Consumer Perceptions of Service Quality. Journal of Retailing, 64, Spring.

Riduwan \& Kuncoro, E. A. (2012). Cara Menggunakan dan Memaknai Path Analysis (Analisis Jalur), CV. Alfabeta, Bandung.

Sartika, Dewi. (2017). Analisis Faktor-Faktor Yang Mempengaruhi Minat Beli Ulang Produk You C 1000 Serta Dampaknya Terhadap Loyalitas Konsumen. Jurnal Penelitian Ekonomi dan Bisnis, 2(1). 10 - 21.

Sulistyawati, Ni Made Arie \& Seminari, Ni Ketut. (2015). Pengaruh Kualitas Pelayanan Terhadap Kepuasan Pelanggan Restoran Indus Ubud Gianyar. E-Jurnal Manajemen Unud, 4(8), Agustus 2015, 2318-2332. Tersedia pada http://ojs.unud.ac.id/index.php/Manajemen/article/view/12882. Diakses pada tanggal 31 Maret 2020.

Tjiptono, Fandy. (2014). Prinsip-Prinsip Total Quality Service, Andy Offset, Yogyakarta.

Vinda, W. Luresia dan Pujotomo, Darminto. (2015). Analisis Pengaruh Kualitas Pelayanan Dan Kualitas Produk Terhadap Minat Beli Ulang (Studi pada Starbucks Semarang). Industrial Engineering Online Journal, 4(4), Tersedia pada http://ejournal-s1undip.ac.id/index.php/ieoj. Diakses pada tanggal 31 Maret 2020.

Wibowo, Ary Wahyu. (2017). Bisnis Kuliner Topang Perekonomian Solo. Tersedia pada Sindonews.com.https://www.google.com/amp/s/ekbis.sindonews.com/newsread/. Terbitan Selasa, 24 Januari 2017/05:16. Diakses pada tanggal 31 Maret 2020.

Windarti, Tias dan Ibrahim, Mariaty. (2017). Pengaruh Kualitas Produk Dan Kualitas Pelayanan Terhadap Kepuasan Konsumen Produk Donat Madu (Studi Pada Konsumen CV. Donat Madu Cihanjuang-Pekanbaru). Jom FISIP, 4(2), Oktober 2017, $1-10$. 